\title{
Prediction of Demersal Fishing Ground Associated with Coral Reefs in the Coastal Jepara Regency, Central Java, Indonesia Based on Sentinel 2a Imagery
}

\author{
Kunarso $^{*}, 1,2$, Muhammad Zainuri ${ }^{1,2}$, Denny Nugroho Sugianto ${ }^{1,2}$, Jarot Marwoto ${ }^{1}$, Hariyadi ${ }^{1}$, Muslim $^{1}$ \\ ${ }^{1}$ Department of Oceanography, Faculty of Fisheries and Marine Science, Diponegoro University, Semarang, Indonesia, Prof. Soedarto, \\ SH Street, Tembalang Phn./Fax. (021) 7474698 Semarang 50275 \\ ${ }^{2}$ Center for Coastal Rehabilitation and Disaster Mitigation Studies (CoREM), Diponegoro University, Center of Excellence Science \\ and Technology (PUI), Indonesia
}

\begin{tabular}{l} 
A R T I C L E I N F O \\
\hline Article history: \\
Received: 11 September, 2019 \\
Accepted: 22 November, 2019 \\
Online: 05 December, 2019 \\
\hline
\end{tabular}

Keywords:

Fishing Ground

Demersal

Sentinel $2 a$

Jepara

\begin{abstract}
A B S T R A C T
Map of prediction of fishing ground that already exists in Indonesia issued by the Bali Marine Research and Observation Center (BPOL) and the National Aeronautics and Space Agency (LAPAN) of Jakarta, there are still many weaknesses including the spatial aspect of the point of forecasting far from the coast and the unclear type of fish predicted. The lack of understanding of the type of fish predicted, the risk of fishermen carrying the wrong fishing gear so that when reaching the forecasting location, fishermen can not catch fish that are abundant. The method of determining fishing ground for demersal fisheries is carried out in three stages, first step, environmental tabulation of demersal fisheries, the second stage of mapping corals area and its supporting parameters, the third stage of mapping the demersal fishing ground. The results of the study obtained several statements, namely demersal fishing ground can be made based on an understanding of childhood fish habitat, adulthood, substrate base habitat, an optimum depth of catchment area. Sentinel $2 A$ satellite imagery can be used to help determine the fishing ground of demersal fish species, but for the coastal waters of Jepara Regency, there are still obstacles related to spatial resolution and water turbidity. Field data is still needed to help determine the demersal fishing ground. Based on the fishing ground mapping, there are four economical types of fishery resources that live in the coral reef environment, namely Lobster, Red Snappers, Blue Line Seabass and Leopard Coral Grouper. The demersal fishing ground associated with corals in the Coastal Jepara Regency Waters which is seven segments apparently only four segments have the potential to become demersal fishing ground associated with coral reefs, namely the second to fourth segments, including the coastal waters of Jepara, Mlonggo, Bangsri, and Kembang. District and the most potential is the coastal waters of the Mlonggo District.
\end{abstract}

\section{Introduction}

Catching systems in Coastal Jepara District are generally still traditional because without the help of high technology, only based on experience or feeling alone. Although the fishing gear used is quite advanced, but the departure to the sea has a very high gambling rate and tends to remain like the catchment area of the previous year. The increasing number of boats, making a fishing ground congested with fishing effort so that the results catch per

*Kunarso, et al., Oceanography Department, Diponegoro University,

+6285875762162.kunarsojpr@yahoo.com

www.astesj.com

https://dx.doi.org/10.25046/aj040633 boat tends to fall from year to year [1]. Fishermen's lack of understanding the temporally and spatially changing of fishing ground due to changes in oceanographic conditions makes fishing more difficult, time and costly-consuming, but the results are less than optimal.

In Indonesia, there are already institutions that make fishing ground predictions, namely BPOL (Research and Marine Observation Center) in Perancak Bali and LAPAN (National Aeronautics and Space Institute), but their utilization of fishing ground prediction is not optimal, because there are still many 
weaknesses that need to be fixed. These weaknesses include locations plotted as potential catchment areas generally in offshore areas so that small fishermen cannot take advantage, forecasting in the form of spots so they do not represent the area, besides that there is no specification of fish species, whether for demersal or pelagic fish species. Different types of fish require different habitat locations and different fishing technologies. Another weakness is the basic data used for forecasting is especially based on two parameters, namely chlorophyll-a (fertility indicator) and sea surface temperature from MODIS imagery, this is certainly not suitable if for forecasting demersal fish [1]

Demersal fisheries types from fishes, crustaceans or mollusks are generally associated with vital habitats in the form of corals, seagrasses and mangroves [2]. Types of demersal fisheries that are associated with coral on the coast of Jepara, for example, lobsters, red snapper, coral grouper and tiger grouper [3]. A good understanding of the location of coral reefs can help identify the demersal fishing ground associated with coral. Sentinel 2 satellite imagery has proven to be very satisfying to be used to identify and monitor coral reefs in coastal waters $[4,5]$ The purpose of this research is to make an innovation in determining the fishing ground for demersal fisheries associated with coral reefs on the coast based on data from sentinel 2 satellite imagery, corals field data, and bathymetry data. Research Location in the coastal waters of Jepara Regency, Central Java Indonesia (Figure $1)$.

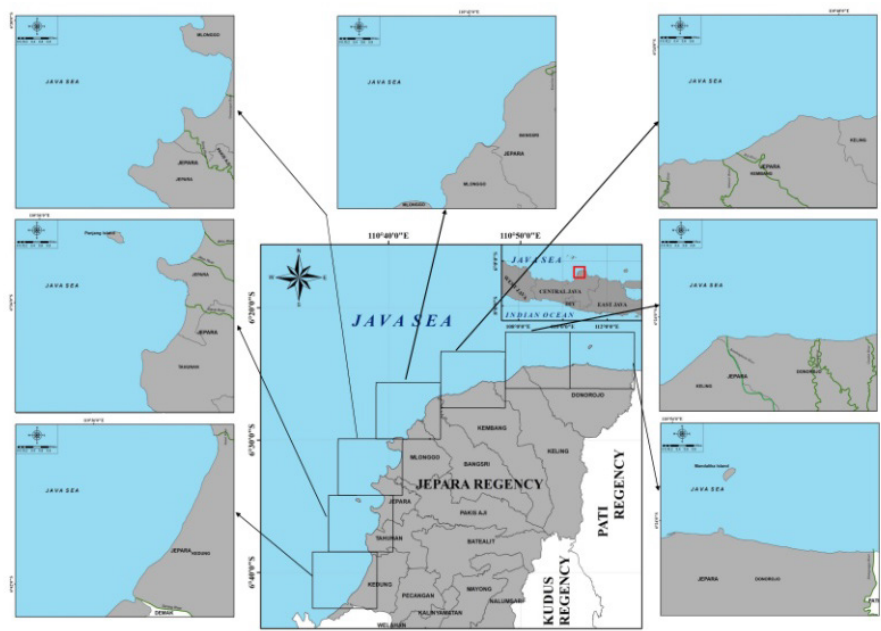

Figure 1: Research Location in the Coastal of Jepara Regency Waters

\section{Materials and Methods}

\subsection{Research Material}

The material used in this study includes main data and supporting data. The main data used consists of vital habitat distribution data, namely the distribution of coral reefs, estuarine locations, besides oceanographic parameter data, including bathymetry, total suspended solids (TSS), and bottom substrate. Supporting data include Jepara Regency marine environment map data and demersal fish bioecology data. The data of corals and TSS
(Total Suspended Solid) were obtained from sentinel-2 satellite image data processing. The coral's distribution data supplemented with field survey data. Bathymetry data from the Navy Hydrooceanography Center (PUSHIDROSAL).

\subsection{Research Methods}

The method used in this study is a descriptive method that seeks to describe the coral's distribution and oceanographic conditions especially TSS that support the life of demersal fish. Furthermore, describe the optimum bioecological factors for demersal fish. The corals, TSS, and the estuary locations are used for delineation (determination) of demersal fish potential prediction in the waters of Jepara Regency.

\section{- Method of Collecting Data}

The Distribution data of coral reefs from Sentinel-2 Imagery, besides corals data, TSS data were also obtained from Sentinel 2 this has been done by researchers [6,7], corals data from field also be surveyed by acoustic check, and estuarine location information used in this study. The Sentinel satellite data was obtained from the web site www.earthexplorer.usgs.gov. The spacial resolution of sentinel image data of $10 \mathrm{~m}$. The water depth data obtaining from earthexplorer.usgs.gov

\section{- Data analysis and Processing}

\section{a. Sentinel-2 Satellite Image Data}

The Sentinel-2 image processing is carried out in several stages, including image correction and processing and using the lyzenga algorithm to determine the extent of corals. The image used in this study is sentinel-2 which has a cloud cover of less than $10 \%$ so that the sea and land look well. Sentinel-2 imagery has 12 bands, in which there are green, blue and NIR channels with various spatial resolutions $(10 \mathrm{~m}, 20 \mathrm{~m}, 60 \mathrm{~m})$. The required channel in the lyzenga algorithm has been fulfilled.

The first stage of sentinel image processing is geometry correction, this correction is done in the global mapper software and aims to bring up coordinates in the image. The second step is radiometry correction, this correction is done in software mapper and aims to eliminate disturbances when recording images. The third stage is determining the extent of corals using the lyzenga algorithm.

The lyzenga algorithm used $[8,5]$

$$
Y=\ln \left(L_{i}\right)-\left[\left(\frac{k i}{k j}\right) x \ln \left(L_{j}\right)\right]
$$

Where:

$L_{i}=$ blue channel reflectant value

$L_{j}=$ the reflectance value of the green channel

$k_{i} / k_{j}=$ ratio of attenuation coefficients of blue and green channels

Equation (1) is used for the extraction of water bottom information $(Y)$. That requires two image spectral channels and ki / kj ratio which is the attenuation coefficient ratio between the two channels, in this case, the blue channel and the green channel. This algorithm calculation is influenced by channel pairs i (blue channel) and $\mathrm{j}$ (green channel) used. The wavelength of the channel used will affect how deep the channel can detect the 
bottom of the water. Blue canals and green canals have the best penetration wavelengths among other channels [5].

The attenuation coefficient $(\mathrm{ki} / \mathrm{kj})$ is calculated by the equation:

$$
\frac{k_{i}}{k_{j}}=a+\sqrt{a^{2}+1}
$$

The value of a is determined by the equation:

$$
a=\frac{\sigma_{i i}+\sigma_{j j}}{2 \sigma_{i j}}
$$

Where: $\sigma_{\mathrm{ii}} \quad=$ channel variety or variant $\mathrm{i}$

$$
\sigma_{\mathrm{jj}} \quad=\text { channel variety or variant }
$$

b. Sentinel-2 Satellite Diagram of Method for Determination of Demersal Fishing Ground

The innovations to create a potential area for demersal fishing ground, carried out with the stages described in three flow diagrams.

- The first stage

The first stage is the environmental tabulation of demersal fisheries. This stage is carried out with reference studies and collecting catch data from the Jepara Regency area which will be predicted for its fishing ground area. This stage is carried out with a reference study from the Department of Maritime Affairs and Fisheries of Jepara Regency and a survey to the Fish Auction Site (TPI) in Jobokuto Jepara, about the types and amount of demersal fish catches. Then conducted to reference study about the bioecology of demersal fish available from various books and websites. The results of this reference study and survey are tabulated in the environmental table for demersal fisheries.

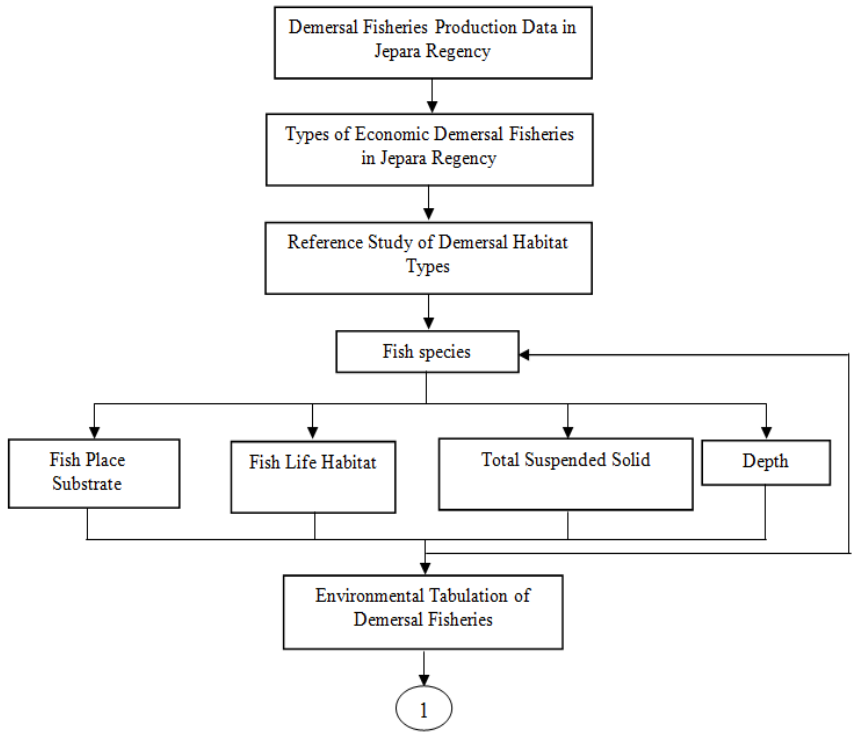

Figure 2: Flow chart of demersal fish environmental tabulation in Jepara Regency

- The second stage

The second stage is the mapping of vital habitat (coral reefs) and its supporting parameters. The second phase is done by downloading Sentinel-2 and bathymetry data, be supported by soft file data of the Jepara Regency environmental map. All data is processed to display the distribution of corals, water depth, TSS and location of river mouths.

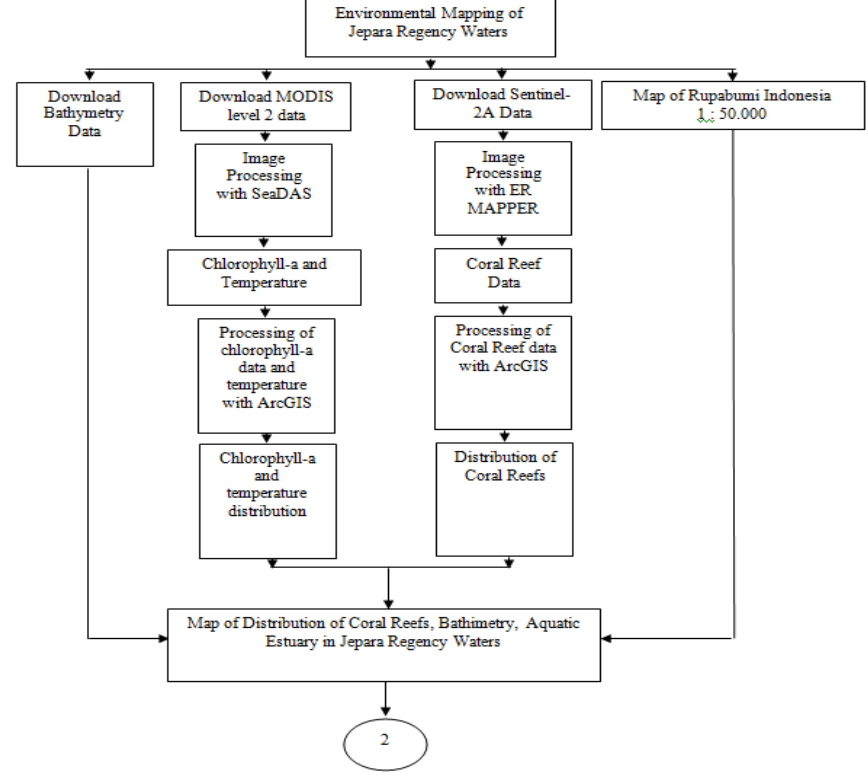

Figure 3: Flow chart of the distribution of vital habitat (coral, estuarine) and environmental conditions on the coast of Jepara Regency

- The third stage

The third stage is mapping the potential area of demersal fish. The third step is verification of field corals data and note the local name of the corals. All data both image data and field data are overlaid so formed maps of corals habitat distribution data and oceanographic factors, including bathymetry and TSS. Subsequently, an analysis was conducted to plot the potential catchment area of demersal fisheries (red snapper, coral grouper, sunu grouper, stingray, and lobster). Plotting of fish potential area based on the environmental

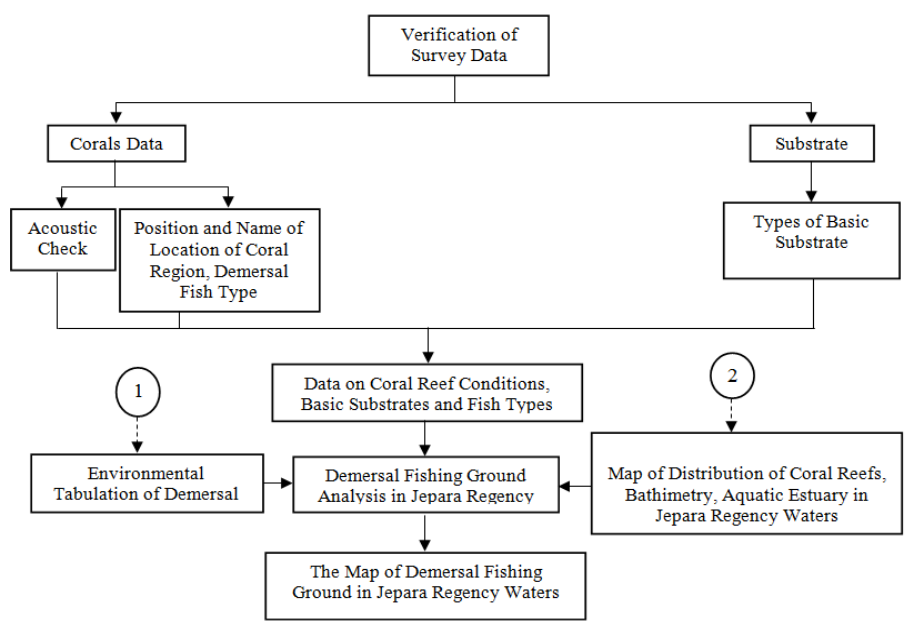

Figure 4. Flow chart prediction of demersal fishing ground mapping on the coast 3. Result and Discussion of Jepara Regency

\subsection{The Economic Demersal Fish Species Associated with Corals in Jepara Coastal Waters}

Based on the reference study and a survey at a fishing landing port in Jepara there are 10 economical demersal fish from Jepara Beach were found, namely Sea Catfishes, Red Snappers, Blue Line Seabass, Leopard Coral Grouper, Hairtails, Rays, 
Lobster, White Shrimp, Rainbow Shrimp and Swimming Crabs (Figure 5). Based on the data there are only 4 types of economic demersal fisheries associated with corals were obtained from Jepara coastal waters, namely: Lobster, Red Snappers, Blue Line Seabass and Leopard Coral Grouper. Based on the environmental types of potential demersal fisheries in Jepara Regency Waters shown in Table 1, Lobster from childhood to adulthood live in a coral environment, a childhood in the bottom of sandy waters and an adult verada in the sidelines or hole of a coral [9]. Red Snappers and, Blue Line Seabass of his childhood life in beaches and river estuaries, but when it has begun to mature migrate to the rocky area [10]. Leopard Coral Grouper in childhood spawn and develop in seagrass areas, but when they mature they migrate to coral reef areas [10]. Demersal fisheries consisting of fish and crustaceans associated with corals are mature and foraging in coral areas. They are caught with fishing gear and traps in the coral reef area. However, when approaching spawning the corals fish migrate to the seagrass, muddy or sandy coastal areas.

Table 1: Environmental Conditions of Economical Demersal Fisheries Fish in Jepara Regency Table

\begin{tabular}{|c|c|c|c|c|c|c|c|}
\hline \multirow[b]{2}{*}{$\begin{array}{l}\mathbf{N} \\
\mathbf{u} \\
\mathbf{m}\end{array}$} & \multicolumn{7}{|c|}{ Type of Habitat/ Associated fish types } \\
\hline & $\begin{array}{c}\text { Corralling } \\
\text { Beach/ } \\
\text { Rocky }\end{array}$ & $\begin{array}{c}\text { Seagrass } \\
\text { Beach }\end{array}$ & $\begin{array}{c}\text { Mangrove } \\
\text { Beach }\end{array}$ & Estuarine & Offshore & Substrate & $\begin{array}{c}\text { Depth/ } \\
\text { Optimum } \\
\text { (meters) }\end{array}$ \\
\hline 1 & $\begin{array}{l}\text { Lobster } \\
\text { (larvae- } \\
\text { adults }\end{array}$ & & & & & $\begin{array}{c}\text { Corals- } \\
\text { sand / } \\
\text { mud- sand }\end{array}$ & $\begin{array}{c}<100 / 7- \\
15\end{array}$ \\
\hline 2 & & & $\begin{array}{c}\text { Sea } \\
\text { Catfishes } \\
\text { (larvae - } \\
\text { young) } \\
\end{array}$ & $\begin{array}{c}\text { Sea } \\
\text { Catfishes } \\
\text { (adult) }\end{array}$ & & mud & $<100$ \\
\hline 3 & $\begin{array}{c}\text { Red } \\
\text { Snappers } \\
\text { (adult) }\end{array}$ & & & $\begin{array}{c}\text { Red } \\
\text { Snappers } \\
\text { (larvae - } \\
\text { young) } \\
\end{array}$ & & $\begin{array}{c}\text { Mud } \\
\text { mixed } \\
\text { with coral } \\
\text { fragments }\end{array}$ & $\mid \begin{array}{c}<100 / 40- \\
70\end{array}$ \\
\hline 4 & $\begin{array}{c}\text { Blue Line } \\
\text { Seabass } \\
\text { (adult) }\end{array}$ & & & $\begin{array}{c}\text { Blue Line } \\
\text { Seabass } \\
\text { (larvae - } \\
\text { young) }\end{array}$ & & & $<40$ \\
\hline 5 & $\begin{array}{l}\text { Leopard } \\
\text { Coral } \\
\text { Grouper } \\
\text { (adult) }\end{array}$ & \begin{tabular}{|c} 
Leopard \\
Coral \\
Grouper \\
(larvae- \\
young) \\
\end{tabular} & & & & & $<40 / 7-9$ \\
\hline 6 & & & & $\begin{array}{c}\begin{array}{c}\text { Hairtails } \\
\text { (lavae) }\end{array} \\
\end{array}$ & $\begin{array}{c}\text { Hairtails } \\
\text { (adult) }\end{array}$ & mud & $\begin{array}{l}<2000 / \\
1-250\end{array}$ \\
\hline 7 & Rays & & & Rays & & Sand-mud & $<90 /<40$ \\
\hline
\end{tabular}

\subsection{Prediction of Demersal Fishing Ground Associated with Corals in the Coastal Jepara Regency}

Determination of demersal fishing ground is different from determining pelagic fishing ground. The fishing ground for demersal fish is closely related to the condition of its vital habitat, namely the location of corals, seagrasses, mangroves, and river mouths. Another limiting factor is the base substrate and the depth of the water. The dependence on these factors makes demersal fishing groundfish such as Red Snapper, Blue Line Seabass, Leopard Coral Grouper, and Lobster likely to remain location. So that our understanding of the habitat location of the demersal fisheries, makes it easier to determine the prediction of its fishing ground.

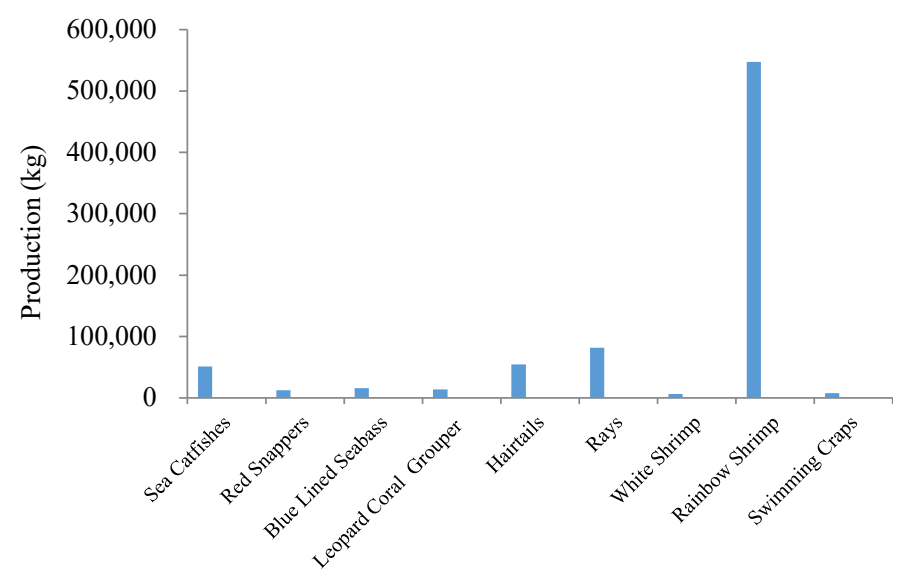

Types Demersal Fishery

Figure 5. Demersal fisheries production in Jepara Regency (DKP Jepara, 2017)

Based on the results of the Sentinel-2 satellite image data processing and field survey, the Jepara Regency Coastal Area from West to East was divided into 7 segments (Figure 1), apparently only 4 segments contained coral reef habitats. The four segments are segment 2 namely the coastal waters of Tahunan and Jepara Districts (Figure 5), segment 3 namely the waters of the Districts of Jepara and Mlonggo (Figure 6), segment 4 namely the coastal waters of the Districts of Mlonggo and Bangri (Figure 7), and segment 5 which is the waters coast of Kembang and Keling Districts (Figure 8).

Three segments were not found coral reefs, that is in segment 1 namely Kedung District Coastal waters, segment 6 namely Keling and Donorojo District Coastal waters and segment 7 in the Donorojo District Coastal waters (Figure 1). Based on the field survey, the three segments that were not found in the coral reef had a substrate dominant with mud.

\section{- Prediction of Demersal Fishing Ground in Segment 2}

Segment 2, which covers the waters of the Tahunan District up to part of Jepara District based on Sentinel-2 satellite imagery and a field survey found 8 groups of coral reefs, with the local name and approximate area of Bokor Reef ( 5 ha), Teluk Awur Reef (12 ha ), Tegal Sambi Reef (3 ha), Dalem Reef (3 ha), Pemandian Reef and Pulau Reef (66.4 ha), Panjang Island Reef ( 8 ha) and Sekumbu Reef (17.5 ha). Based on Sentinel-2 imagery, all clusters of reefs can be identified in terms of area and position, except for Bokor Reef only identified with field survey by snorkeling.

Seven other coral reef visible from Sentinel imagery are predicted as demersal fishing ground, especially type of fish Red Snappers, Blue Line Seabass and Leopard Coral Grouper, in green clusters (Figure 5). The highest potential demersal fishing ground 
in terms of the extent of coral reef is predicted to be in the east coast region of Jepara District, which is along the location between Pemandian Reef and Sekumbu Reef.

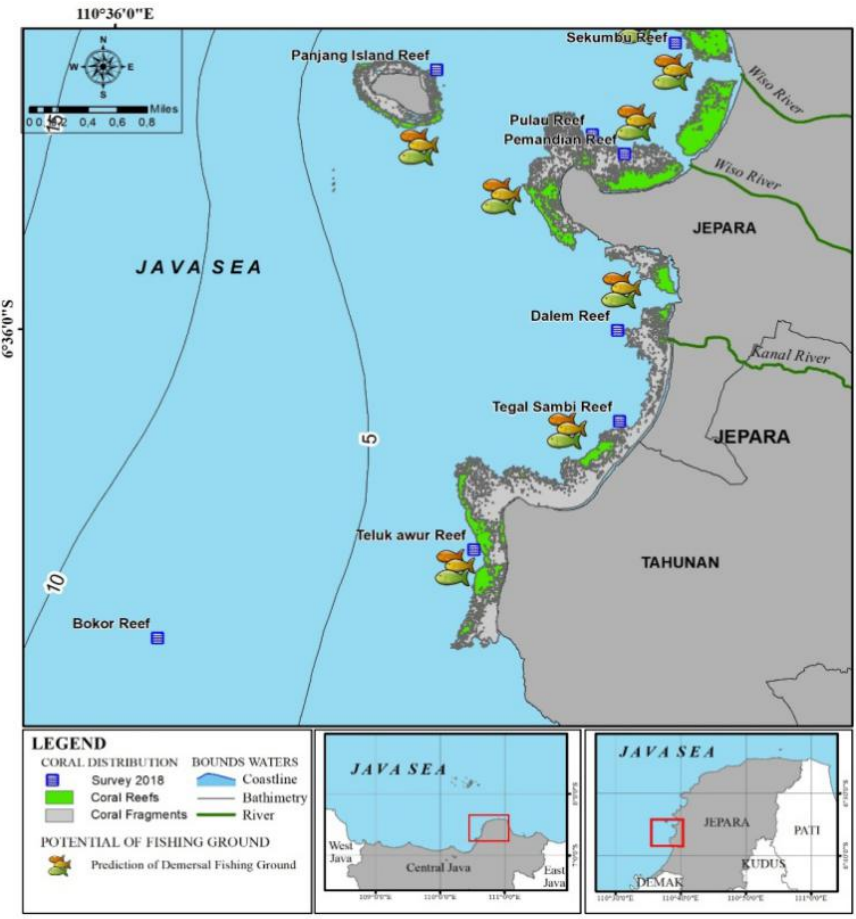

Figure 5. Predictions of potential fishing ground associated with corals in Coastal of Jepara segment 2 (Tahunan and Jepara Districts)

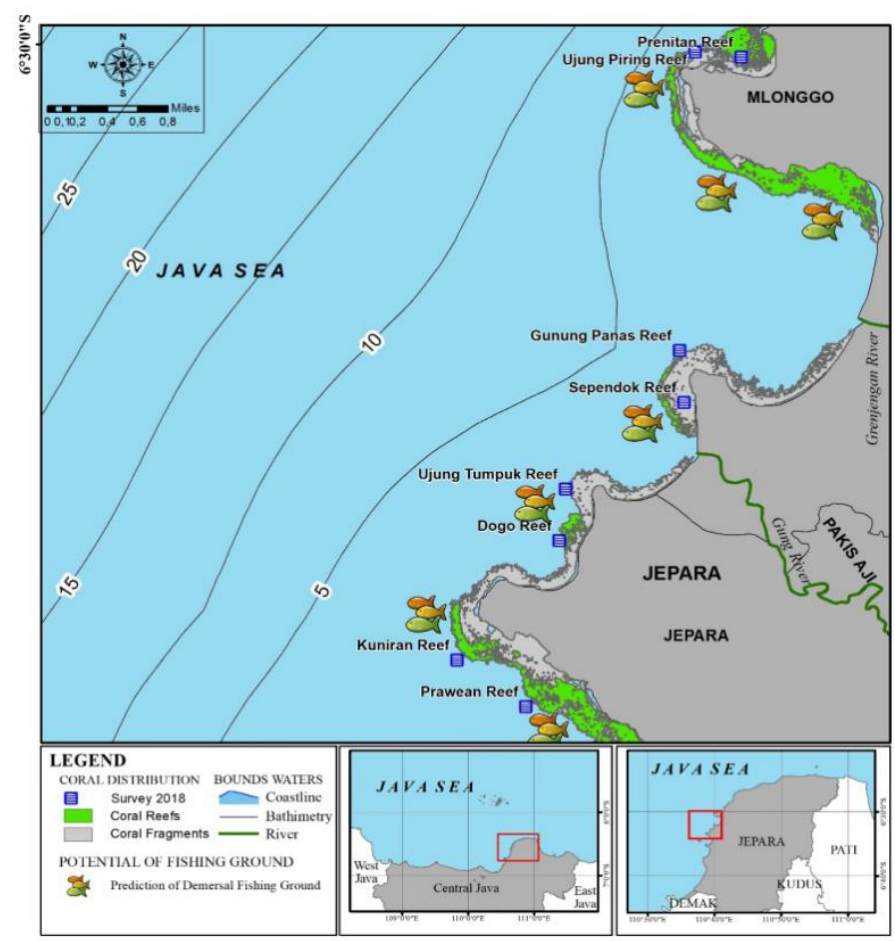

Figure 6. Predictions of potential fishing ground associated with corals in Coastal of Jepara segment 3 (Jepara and Mlonggo Districts)

- Prediction of Demersal Fishing Ground in Segment 3

Segment 3, which covers the waters of the Jepara District up to part of Mlonggo District based on Sentinel-2 satellite imagery and a field survey found 8 groups of coral reefs, with the local name and approximate area of Prawean Reef (17.5 ha), Kuniran Reef (38 ha ), Dogo Reef (10 ha), Ujung Tumpuk Reef (14 ha), Sependok Reef (20 ha), Gunung Panas Reef (9 ha), Ujung Piring Reef (39 ha) and Prenitan Reef (9 ha) (Figure 6).

Six coral reef visible from Sentinel imagery are predicted as demersal fishing ground, especially type of Red Snappers, Blue Line Seabass and Leopard Coral Grouper, and lobster in green clusters (Figure 6). The Six coral reef are Prawean Reef, Kuniran Reef, Dogo Reef, Sependok Reef, Ujung Piring Reef, and Prenitan Reef. The highest potential demersal fishing ground in terms of the extent of coral reef is predicted to be in the coast region of Mlonggo District, which is along the location between Ujung Piring Reef than followed Prawean Reef.

\section{- Prediction of Demersal Fishing Ground in Segment 4}

Segment 4, which covers the waters of the Mlonggo District up to part of Bangsri District based on Sentinel-2 satellite imagery and a field survey found 9 groups of coral reefs, with the local name and approximate area of Semayit Reef ( 2 ha), Sejongok Reef (5 ha ), Purancak Reef ( 5 ha), Kemangi Reef ( 5 ha), Ombo Reef (19.6 ha), Pandan Reef ( 2 ha), Lasak Reef (9 ha) and Ngelo Utara Reef (dead) dan Selaran Reef (dead) (Figure 7).

Four coral reefs visible from Sentinel imagery are predicted as demersal fishing ground, especially type of Red Snappers, Blue Line Seabass and Leopard Coral Grouper, and lobster in green clusters (Figure 7). The Four coral reef are Sejengok Reef, Purancak Reef, Ombo Reef, and Lasak Reef. The highest potential demersal fishing ground in terms of the extent of coral reef is predicted to be in the coast region of Ombo District, which is in offshore depth $10 \mathrm{~m}$ than followed Lasak Reef.

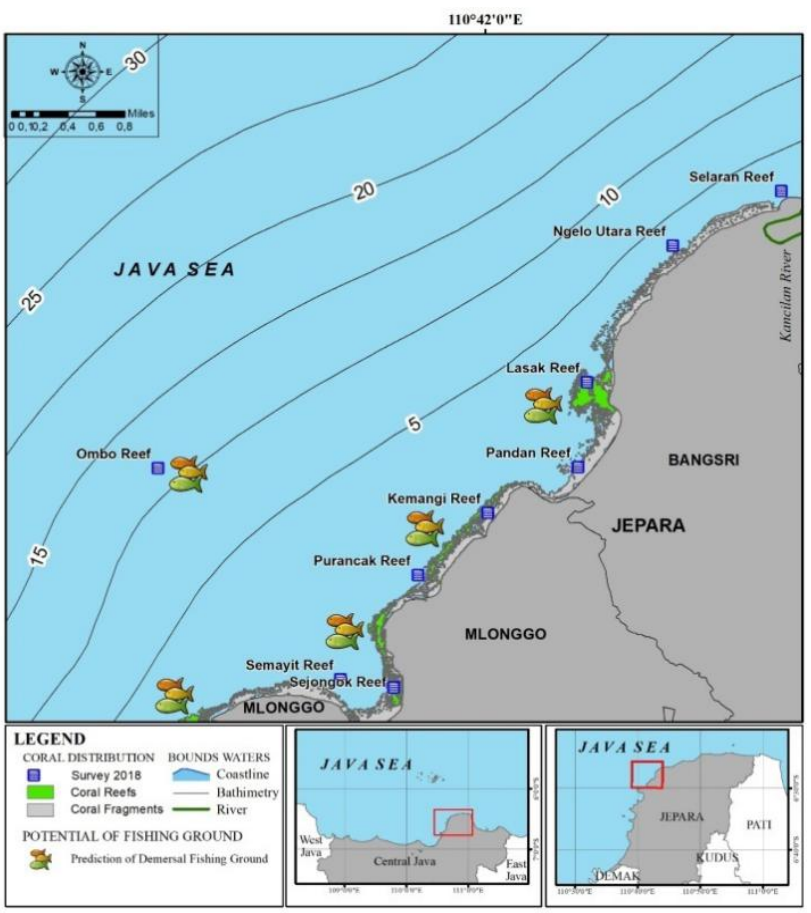

Figure 7. Predictions of potential fishing ground associated with corals in Coastal of Jepara segment 4 (Mlonggo and Bangsri Districts) 


\section{- Prediction of Demersal Fishing Ground in Segment 5}

Segment 5, which covers the waters of the Kembang District up to part of Keling District based on Sentinel-2 satellite imagery and a field survey found only one group of coral reefs, with the local name and approximate area is Segedek Reef (10 ha) (Figure 8). Segedek Coral reef is about $4 \mathrm{~m}$ under surface waters, it's location in the Coastal of Keling District. That coral reefs are found by field survey predicted as demersal fishing ground, especially the type of Red Snappers, Blue Line Seabass and Leopard Coral Grouper, and lobster (Figure 8).

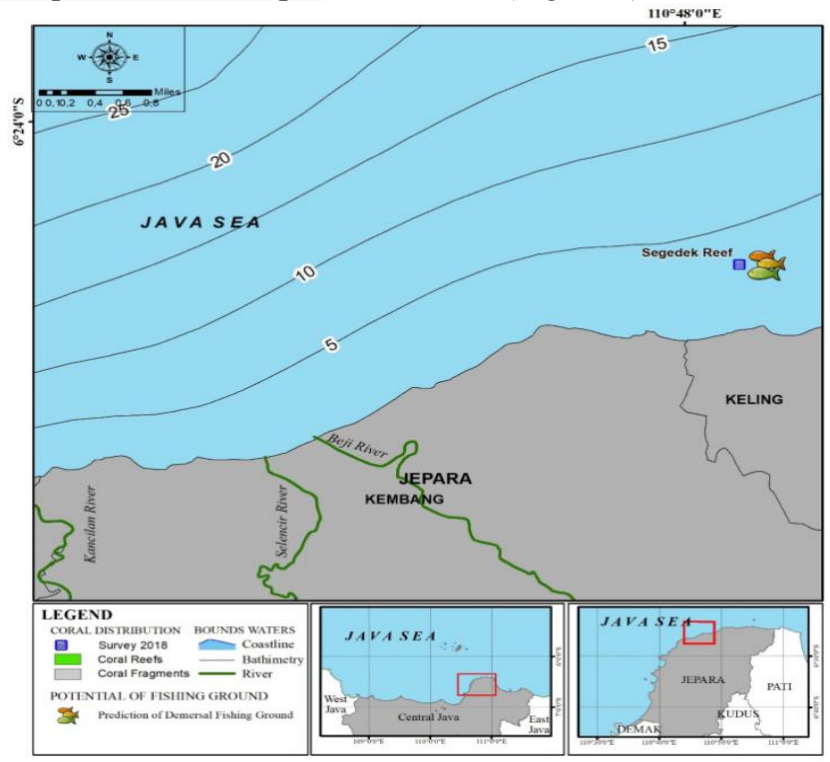

Figure 8. Predictions of potential fishing ground associated with corals in Coastal of Jepara segment 5 (Kembang and Keling Districts)

- Limitations on the use of Sentinel-2 Satellite Imagery to be applied to Corals

The use of Sentinel-2 satellite imagery to analyze the distribution of coral reefs in the coastal area of Jepara Regency turned out to be a problem so that some areas were not visible. Two things that are suspected as the main cause are spatial resolution and water turbidity.

\subsection{Spatial Resolution}

The sentinel image is used sentinel $2 \mathrm{~A}$, with a spatial resolution of $10 \mathrm{~m}$. This pixel is influenced by the environment inside the pixel itself and outside the pixel. If the pixel is dominated by sand with only a few corals, then the coral will be invisible. Likewise, the environment around the pixel also affects, if around the pixel it turns out to be dominated by sand, while appears is sand. So that one pixel of coral can be seen the coral then there is a minimum of $3 \times 3$ pixels covered by coral. This is in accordance with what explained, which states that pixels outside the sample area need to be considered, and related to the size of the object (too small) will be a difficulty. So for the use of sentinel $2 \mathrm{~A}$ imagery, the minimum coral cover that can be identified is $30 \mathrm{~m}^{2}$. Examples of corals in Jepara that are present but not visible in the image are Karang Bokor on the west coast of Teluk Awur, Karang Ombo, Karang Mandalika and Karang Beteng (Figures 5, 7 and 9).

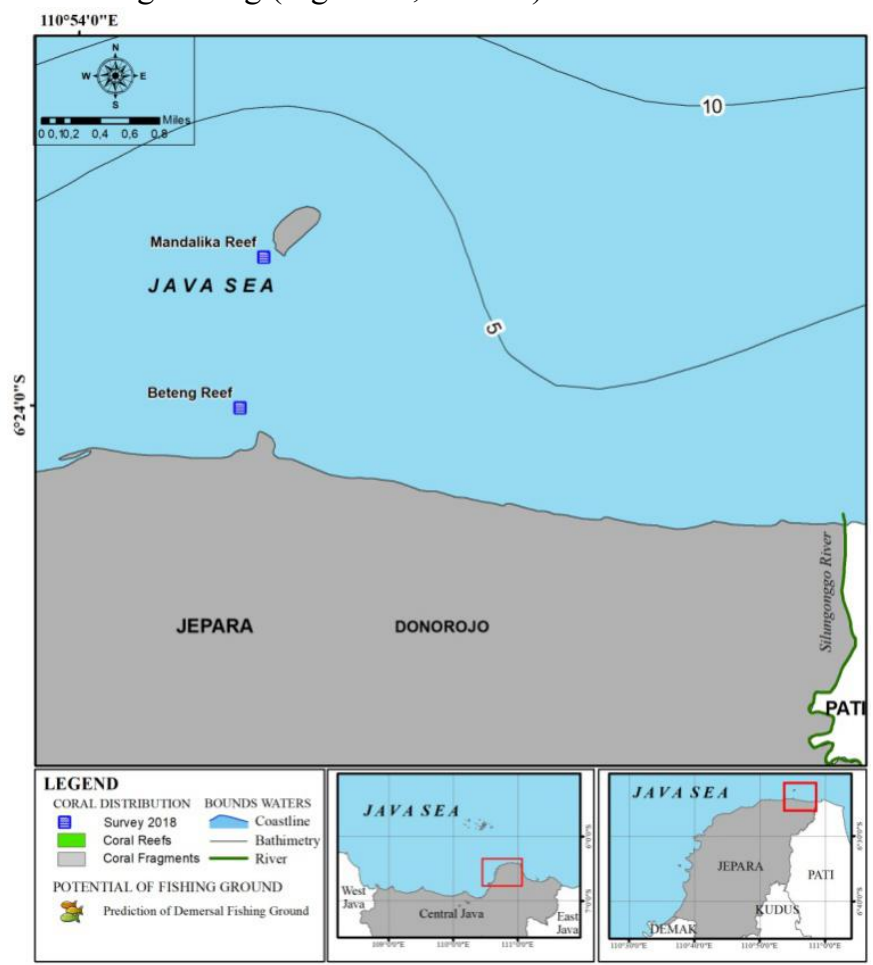

Figure 9. Beteng Reef and Mandalika Reef based on field surveys found its location in the northern waters of the Donorojo Regency, but from Sentinel Citra2 it was not seen.

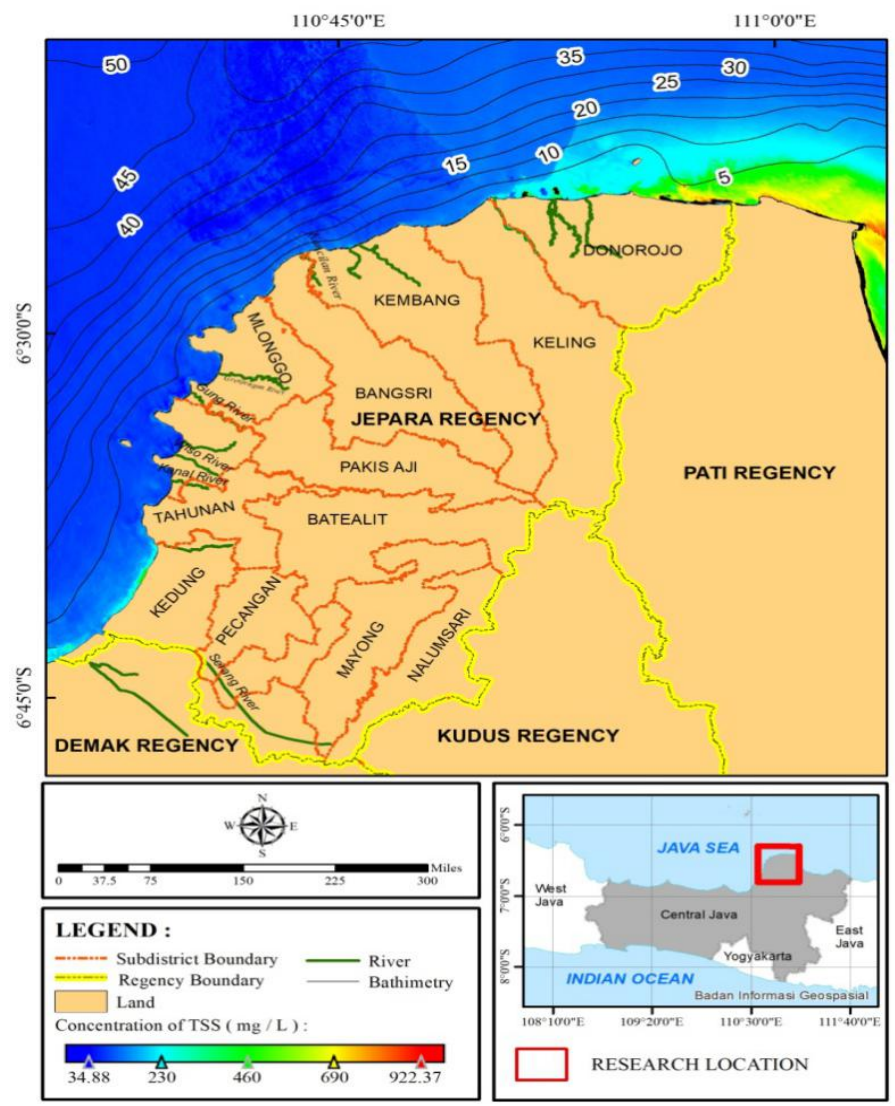

Figure 10. The Coastal Waters Northern Donorojo District and Western Kedung District contain high turbidity because high TSS (in the red squares) 


\subsection{Water Turbidity}

Water turbidity is a serious obstacle. Coral reefs habitats in the northern coastal region, starting from Keling, Kembang, Donorojo District Waters with identification using Sentinel 2A images, did not show any coral. This is thought to be related to the high turbidity value, which is caused by the flow of rivers carrying mud from the Pati District area. Water masses carrying high Total Suspended Solids (TSS) values with range concentration $250-690 \mathrm{mg} / \mathrm{L}$ (Figure 10) are carried by ocean currents entering the Jepara region (Figure 10). This high TSS mass makes the sun's electromagnetic energy unable to penetrate the water so that the coral objects are not visible. Presumably, the reflection of the suspended solids, makes the sea surface closed, and looks like sand (Figure 10).

\section{Conclusion}

Innovation of demersal fishing ground prediction can be done in three stages, fist tabulating demersal fisheries environmental conditions, second mapping of vital habitat (coral reefs) and its supporting parameters, third mapping prediction of the potential area of demersal fish. Namely, demersal fishing ground can be made based on an understanding of childhood fish habitat, adulthood, substrate base habitat, an optimum depth of catchment area. Sentinel satellite imagery can be used to help determine the fishing ground of demersal fish species, but for the coastal waters of Jepara Regency, there are still obstacles related to spatial resolution and water turbidity. Field data is still needed to help determine the demersal fishing ground. Based on the fishing ground mapping, there are four economical types of fish that live in the coral reef environment, namely lobster, red snapper, coral grouper, and tiger grouper. The demersal fishing ground associated with corals in the Coastal Jepara Regency Waters which is seven segments apparently only four segments have the potential to become demersal fishing ground associated with corals, that are the second to fourth segments, including the coastal waters of Jepara, Mlonggo, Bangsri and Kembang District and the most potential is the coastal waters of Mlonggo District.

\section{Acknowledgment}

We thank the Diponegoro University for receipt of research funds with contract number 1501-33 / UN7.5.10 / LT / 2018 and Head of the Oceanography Department, Dr. Denny Nugroho S, ST., M.Sc, for the support of easy research administration. We also thank two of my assistants namely Mr. Bayu Munandar and Mr.Dika Ahmad Rojikin for their help so far.

\section{References}

[1] Kunarso, "Opportunities for Improvement of Fish Potential Location Forecast Models (Development of New Models for Increasing the Accuracy and Coverage of Fishing Area", Paper of Focus Group Discussion in Topics "Maximizing Fish Potential Information for Fishermen" in the forum ICCTF ( Indonesian Climate Change Trust Fund) and National Planning Agency of the Republic of Indonesia (BAPENAS), Jakarta June $30^{\text {th }} 2014$, 16 pages, 2014.
[2] Lalli, C.M. and Parson, T.R., "Biological Oceanography: An introduction", Pergamon, BPC Wheatons Ltd, British.1994

[3] DKP Jepara (Jepara Regency Fisheries Service), "Profile Book of Fisheries Sector in Jepara Regency", Fisheries Service, Jepara Regency GovernmentIndonesia, 51 pages, 2017.

[4] Hedley, J.D., Roelfsemab, C., Brandoc, V., Giardinoc, C., Kutserd, T., Phinnb, S., Mumbye, P.J., Barrilerof, O., Laporteg, J., Koetzh, B., "Coral reef applications of Sentinel-2: Coverage, characteristics, bathymetry and benthic mapping with comparison to Landsat 8", Remote Sensing of Environment. Vol. 216: 598-614 pp, 2018. https://doi.org/10.1016/j.rse.2018.07.014

[5] Jaelani L M, Laili N, and Marini. Y, "Pengaruh Algoritma Lyzenga dalam Pemetaan Terumbu Karang Menggunakan Worldview-2, Studi Kasus: Perairan PLTU Paiton Probolinggo". Research Report: Institusi Teknologi Sepuluh Nopember, Surabaya Indonesia, 2015.

[6] Gernez, P., Lafon, V., Lerouxel A., Curti C., Lubac, B., Cerisier,S., Barile', L., "Towar Sentinel-2 High Resolution Remote Sensing of Suspended Particulate Metter in Very Turbit Waters: SPOT4 (Take5), Experiment in the Laore and Geronde Estuaries", Remote Sensing, 7, 9507-9528, 2015. DOI: 10.3390/rs 70809507.

[7] Bioresita F., Pribadi, C.B., Firdaus, H.S., Hariyanto, T., Puissant, A., "The Use of Sentinel-2 Imagery to Total Suspended Solids (TSS) Estimation in Porong River", Sidoarjo, Elipsoida Vol. 01, No 01, 2018.

[8] Green, E., Edwards, A. and Mumby, P., "Mapping bathymetry" In A.J. Edwards (Ed.), Remote sensing handbook for tropical coastal management (pp.219-234). Paris: UNESCO, 2000.

[9] Holthuis, L.B.," FAO Species Catalogue. Vol. 13. Marine Lobsters of the World", An annotated and illustrated catalog of species of interest to fisheries known to date, FAO Fisheries Synopsis, No. 125, Vol. 13. Rome, FAO. 1991. 292 p, 1991

[10] Habibi, A., Sugianta, Yusuf, C., "Grouper and Snapper Fish- Guidelines for Catching and Handling", Word Wildlife Fund (WWF) Indonesia, 34 pages, 2011 